\title{
Hazai termesztésű gyógynövények és gyümölcsök felhasználása funkcionális élelmiszerek előállítására
}

\author{
Laura Jurecska: The use of Hungarian herbs and fruits for functional food production
}

\section{Summary}

The bioactive components are usually sensitive to environmental impacts and circumstances of technological processes. During the production of functional foods it is necessary to preserve the stability of bioactive components. An often applied method of stability preservation is microencapsulation.

The aim of our research is to encapsulate herbs (lemon balm, garden and Spanish thyme) and color-rich fruits (blackberry, cherry, elderberry and sea-buckthorn) grown in Hungary and having significant antioxidant capacity. Extracts were made from these herbs and fruits with different extractans and the antioxidant capacity of them was studied applying DPPH (1,1-diphenyl-2picrylhydrazyl) method.

These extracts and fruit concentrates were used in microencapsulation experiments applying ,in situ gelation" method. The antioxidant capacity of the microcapsules was determined immediately after preparation and after $\mathbf{2}$ and 4 weeks of storage.

Comparing the antioxidant capacity of the extracts, concentrates and the stored microcapsules a proposal was given for the optimal composition of the encapsulating mixture and long-term storage experiments were started.

Keywords: microcapsule, antioxidant capacity, herb, storage experiment, in situ gelation

\section{ÖSSZEFOGLALÓ}

A bioaktív komponensek érzékenyek a környezeti hatásokra és a technológiai folyamatok körülményeire, ezért ezeknek az anyagoknak a védelmét biztosítani kell, melynek hatékony módszere a mikrokapszulázás. Kutatásaink célja Magyarországon termesztett, jelentős antioxidáns kapacitással bíró gyógy- és füszernövények (orvosi citromfü, kerti és spanyol kakukkfü), valamint színanyagokban gazdag gyümölcsféleségek (fekete bodza, szeder, cseresznye és homoktövis) kivonatainak és súrítményeinek mikrokapszulázása és funkcionális élelmiszerekben való felhasználása.

Kísérleteink első eredményeit összegezve megállapítottuk, hogy a két gyógynövény esetében a növények kivonatának felhasználásával előállított, míg a bogyós gyümölcsök esetében a sürítmény felhasználásával legyártott mikrokapszulák antioxidáns kapacitása kiemelkedő és ezeket a kapszula-változatokat hoszszabb távú eltartási kísérleteknek is érdemes alávetni.

Kulcsszavak: mikrokapszula, antioxidáns kapacitás, gyógynövény, tárolási kísérlet, in situ gélesedés

\section{BEVEZETÉS}

A funkcionális élelmiszerek közé azokat a feldogozott élelmiszereket soroljuk, amelyek élettani szempontból kedvező komponenseket tartalmaznak. Mivel a bioaktív komponensek érzékenyek a különböző környezeti hatásokra $(\mathrm{pH}$, hőmérséklet, oxigén jelenléte, nedvesség, besugárzás) és a technológiai folyamatok körülményeire, a hatóanyagok védelmét valamilyen módon biztosítani kell. Ennek egyik hatékony módszere a mikrokapszulázás. Kutatásaink 
célja Magyarországon termesztett, jelentős antioxidáns kapacitással bíró gyógy- és füszernövények, valamint színanyagokban gazdag gyümölcsféleségek kivonatainak és súrítményeinek mikrokapszulázása és funkcionális élelmiszerekben való felhasználása.

\section{ANYAGOK, MÓDSZEREK}

A kísérletekben felhasznált gyógynövények az orvosi citromfú levél (Melissae folium), valamint a kerti és a spanyol kakukkfü levele és virága (Thymi herba), a Herbária Zrt. gyógyszerkönyvi minőségú termékei voltak. A vizsgált gyümölcsféleségek a fekete bodza (Sambucus nigra), a szeder (Rubus caesius), a cseresznye (Prunus cerasus) és a homoktövis (Hippophae rhamnoides) voltak, melyeket frissen, termelőktől szereztünk be, illetve néhány esetben fagyasztott gyümölcsökkel is dolgoztunk. A kísérletek során felhasználtunk egy kereskedelmi forgalomban kapható, bogyós gyümölcsökből előállított sürítményt is, melynek összetétele szabadalmi oltalom alatt áll, ezt a továbbiakban „BO” rövidítéssel szerepeltetjük. Végeztünk kísérleteket kereskedelmi forgalomban kapható homoktövis alapú készítményekkel is. A „H1" jelű készítmény a homoktövisen kívül almából, tengeri barnamoszat-kivonatból, aszkorbinsavból és E-vitaminból készült; a „H3” jelű készítmény a homoktövisvelőn kívül porított acerola gyümölcsöt tartalmazott.

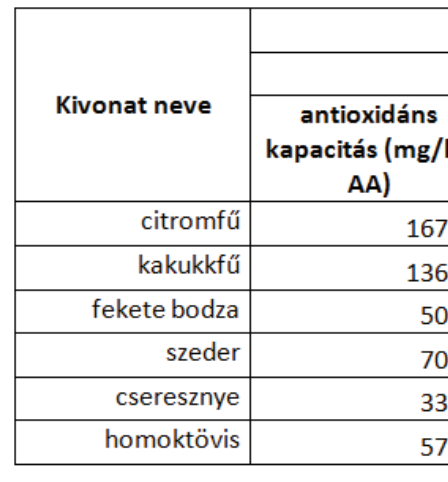

gyümölcsöket, illetve gyógynövényeket turmixgéppel aprítottuk és $1 \mathrm{~g}$ növényi anyag / $20 \mathrm{ml}$ oldószer arány mellett összekevertük az oldószerrel. A mintákat ezt követően ultrahangos kezelésnek vetettük alá, ügyelve arra, hogy a a hatóanyagok védelme érdekében - hőmérséklet ne emelkedjen $30^{\circ} \mathrm{C}$ fölé. Az ultrahangos kezelést 3 szakaszban végeztük, egy szakasz $3 \times 30$ percig tartott, az egyes szakaszokat követően az oldószert cseréltük. Az elkészült kivona-

tok antioxidáns kapacitását DPPH-módszerrel, összpolifenol tartalmát Folin-Ciocalteumódszerrel vizsgáltuk. (A DPPH a difenil-pikrilhidrazil gyök rövidítése, a gyök lila színének 518 nm-en mért, az antioxidáns tulajdonságokkal rendelkező szubsztrát hatására bekövetkező intenzitás csökkenését mérjük. Az eredményeket aszkorbinsavra vonatkoztatva adjuk meg. A Folin-Ciocalteu-módszer alapja, hogy a reagensben lévő foszfomolibdát reakcióba lép az oldatban található polifenolokkal, s velük kék színű komplexet képez, mely kék szín intenzitása arányos az oldatban található polifenolok mennyiségével, $s$ az intenzitás változása fotometriásan, 750 nm-en detektálható.)

Az elkészült növényi kivonatokat, illetve a gyümölcs súrítményeket $1 \mathrm{~m} / \mathrm{m} \%$ nátrium-alginátot és $0,75 \mathrm{~m} / \mathrm{m} \%$ rezisztens keményítőt tartalmazó oldathoz kevertük, az így kapott oldatot csepegtettük kalcium-klorid $2 \mathrm{~m} / \mathrm{m} \%$-os oldatába. A kialakult mikrokapszulákat Büchner-tölcsér segítségével leszűrtük. A mikrokapszulákból közvetlenül az elkészítés után, majd 2, illetve 4 hét elteltével antioxidáns kapacitást mértünk DPPH-módszerrel.

\section{EREDMÉNYEK ÉS ÉRTÉKELÉSÜK}


kivonatra mért értéknek (117770, illetve 16780 $\mathrm{mg} / \mathrm{kg} \mathrm{AA}$ ), de az összpolifenol tartalomban is több, mint háromszoros volt a különbség (71030, illetve 19870 mg/kg GA). A kakukkfü esetében a vizes extraktum antioxidáns kapacitása kétszerese volt az etanollal készült kivonatra kapott értéknek (28230, illetve $13660 \mathrm{mg} / \mathrm{kg}$ $A A)$. Ha nem is ilyen nagy mértékű, de még mindig jelentős különbség volt az etanolos és a vizes extraktum antioxidáns kapacitása és összpolifenol tartalma között a szeder és a fekete bodza esetében. Mindkét vizsgált növény esetében a vizes kivonatból mértük a magasabb értékeket, különösen az összpolifenol tartalomban tapasztaltunk jelentős eltéréseket, a szeder esetében a vizes kivonat háromszor (6520, illetve $2080 \mathrm{mg} / \mathrm{kg} \mathrm{GA}$ ) a fekete bodza esetében több, mint kétszer nagyobb értéket adott (9300, illetve $3460 \mathrm{mg} / \mathrm{kg}$ GA). A cseresznye és a homoktövis esetében nem volt jelentős különbség a kétféle oldószerrel készült kivonat antioxidáns kapacitása és összpolifenol tartalma között.

\begin{tabular}{|l|r|r|r|r|}
\hline \multirow{2}{*}{$\begin{array}{c}\text { Kapszula állapo- } \\
\text { ta }\end{array}$} & \multicolumn{4}{|c|}{ Kapszula típusa } \\
\cline { 2 - 5 } & \multicolumn{2}{|c|}{ citromfü } & \multicolumn{2}{c|}{ kakukkfü } \\
\cline { 2 - 5 } & $\mathbf{5}$ & $\mathbf{1 0}$ & $\mathbf{5}$ & \multicolumn{1}{c|}{10} \\
$\mathrm{~m} /$ & $\mathrm{m} / \mathrm{m}$ & $\mathrm{m} / \mathrm{m}$ & $\mathrm{m} / \mathrm{m} \%$ \\
\hline frissen, nedvesen & 919 & 1255 & & $5740 \pm$ \\
& $0 \pm 1$ & $0 \pm 10$ & $5050 \pm$ & 610 \\
\hline 2 hét tárolás & 910 & 1158 & & $5720 \pm$ \\
után, szárazon & $0 \pm 1$ & $0 \pm 11$ & $4410 \pm$ & 210 \\
& 220 & 30 & 110 & \\
\hline 4 hét tárolás & 740 & 1004 & & $4280 \pm$ \\
után, szárazon & $0 \pm 6$ & $0 \pm 54$ & $3890 \pm$ & 220 \\
\multicolumn{2}{|c|}{20} & 0 & 150 & \\
\hline
\end{tabular}

2. táblázat: Gyógynövények kivonatát tartalmazó mikrokapszulák antioxidáns kapacitása (mg/kg AA) a tárolási kísérlet különböző fázisaiban

Amint azt a 2. táblázat adatai is szemléltetik a citromfú kivonat 117770 mg/kg AA értékűnek mért antioxidáns kapacitásától jelentősen elmarad a frissen elkészített - 5, illetve 10 $\mathrm{m} / \mathrm{m} \%$ növényi kivonatot tartalmazó mikrokapszulák aszkorbinsav egyenértékben kifejezett 9190 \pm 1530 , illetve 12550 \pm 1060 mg/kg-os antioxidáns kapacitása, amely azonban még így is magas értéknek számít. Négy hét tárolást követően valamelyest csökkent a minták antioxidáns kapacitása: $7400 \pm 620$, illetve $10040 \pm 540 \mathrm{mg} / \mathrm{kg}$ AA értékeket mértünk, ez átlagosan $20 \%$ antioxidáns kapacitás csökkenésnek felel meg. Hasonló megállapítást tehetünk a kakukkfű esetében, ahol a kivonatra $28230 \mathrm{mg} / \mathrm{kg}$ AA értéket kaptunk, a frissen készített mikrokapszulákra 5050 \pm 290 , illetve $5740 \pm 610 \mathrm{mg} / \mathrm{kg}$ AA-t. A 4 hetes tárolást követően a kétfele mikrokapszula-változat antioxidáns kapacitása rendre 3890 \pm 50 , illetve $4280 \pm 220 \mathrm{mg} / \mathrm{kg}$-nak adódott aszkorbinsav egyenértékben kifejezve, ami átlagosan $24 \%$ antioxidáns kapacitás visszaesést jelent. Ezek alapján megállapítottuk, hogy az általunk előállított citromfú, illetve kakukkfü extraktumot tartalmazó kapszulák legalább 1 hónapig eltarthatók úgy, hogy még a tárolási időszak végén is jelentős az antioxidáns kapacitásuk.

A rövid távú tárolási kísérletek eredményei alapján úgy döntöttünk, hogy hosszabb távú (3, illetve 6 hónapos) tárolási vizsgálatokat az eddigiekhez képest módosított kapszula összetételekkel - a kapszulázó elegyben a gyógynövény kivonatok arányát megnövelve - végezzük el.

A 3. táblázat adataiból megállapíthatjuk, hogy a bogyós gyümölcsök kivonatával készített mikrokapszulák antioxidáns kapacitása jelentősen lecsökkent az 1 hónapos tárolás során. $\mathrm{A}$ fekete bodza esetében a mikrokapszulázási kísérletben felhasznált kivonat antioxidáns kapacitása $5090 \mathrm{mg} / \mathrm{kg}$ AA volt, amely $2640 \pm 300$, illetve $2780 \pm 270 \mathrm{mg} / \mathrm{kg}$ AA értékre csökkent a kétféle mikrokapszula-változat esetében. A rövid távú tárolási kísérlet végén az antioxidáns kapacitás 1620 \pm 770 , illetve $900 \pm 180 \mathrm{mg} / \mathrm{kg}$ AA volt, ami átlagosan $54 \%$-os csökkenésnek felel meg. A szederből készült vizes extraktumra $7000 \mathrm{mg} / \mathrm{kg}$ AA antioxidáns kapacitás értéket mértünk, a frissen elkészített kapszulákra $2350 \pm 260$, illetve $3480 \pm 500 \mathrm{mg} / \mathrm{kg}$ AA egyenértéket. $A$ szeder kivonatával készült kapszulák voltak azok, amelyek legtöbbet veszítettek antioxidáns kapacitásukból a 4 hét alatt 
Jurecska Laura - Hazai termesztésű gyógynövények és gyümölcsök felhasználása...

\begin{tabular}{|c|c|c|c|c|c|c|}
\hline \multirow{3}{*}{ Kapszula állapota } & \multicolumn{6}{|c|}{ Kapszula típusa } \\
\hline & \multicolumn{2}{|c|}{ fekete bodza } & \multicolumn{2}{|c|}{ szeder } & \multicolumn{2}{|c|}{ cseresznye } \\
\hline & $5 \mathrm{~m} / \mathrm{m} \%$ & $10 \mathrm{~m} / \mathrm{m} \%$ & $5 \mathrm{~m} / \mathrm{m} \%$ & $10 \mathrm{~m} / \mathrm{m} \%$ & $5 \mathrm{~m} / \mathrm{m} \%$ & $10 \mathrm{~m} / \mathrm{m} \%$ \\
\hline frissen, nedvesen & $2640 \pm 300$ & $2780 \pm 270$ & $2350 \pm 260$ & $3480 \pm 500$ & $1730 \pm 210$ & $2710 \pm 190$ \\
\hline $\begin{array}{l}2 \text { hét tárolás után, } \\
\text { szárazon }\end{array}$ & $2380 \pm 180$ & $2710 \pm 270$ & $2100 \pm 180$ & $3290 \pm 440$ & $610 \pm 200$ & $990 \pm 210$ \\
\hline $\begin{array}{l}4 \text { hét tárolás után, } \\
\text { szárazon }\end{array}$ & $1620 \pm 770$ & $900 \pm 180$ & $720 \pm 220$ & $1110 \pm 150$ & $550 \pm 100$ & $920 \pm 210$ \\
\hline
\end{tabular}

3. táblázat: Bogyós gyümölcsféleségek kivonatát tartalmazó mikrokapszulák antioxidáns kapacitása ( $\mathrm{mg} / \mathrm{kg} \mathrm{AA}$ ) a tárolási kísérlet különböző fázisaiban

(69\%-ot): a tárolási időszak végén $720 \pm 220$, illetve $1110 \pm 150 \mathrm{mg} / \mathrm{kg}$ AA értéket kaptunk. A cseresznyéből készült, $3340 \mathrm{mg} / \mathrm{kg}$ AA antioxidáns kapacitású kivonat felhasználásával $1730 \pm 210$ és $2710 \pm 190 \mathrm{mg} / \mathrm{kg}$ AA antioxidáns kapacitású kapszulákat tudtunk készíteni, melyekre - 1 hónap után - a következő eredményeket kaptuk: $550 \pm 100$ és $920 \pm 210 \mathrm{mg} / \mathrm{kg}$ AA. A cseresznye kivonatát tartalmazó mikrokapszulák antioxidáns kapacitása tehát $67 \%$-kal csökkent 4 hét alatt.

Végeztünk elővizsgálatokat a BO jelü gyümölcs sürítményt tartalmazó kapszulákkal is. A kapott eredményeket az "A" (rezisztens keményítő nélküli) és a „ $B$ ” (rezisztens keményítőt tartalmazó) mikrokapszula-változatokra a 4 . táblázatban foglaljuk össze.

\begin{tabular}{|l|c|c|}
\hline \multirow{2}{*}{ Kapszula állapota } & \multicolumn{2}{|c|}{ Kapszula típusa } \\
\cline { 2 - 3 } & \multicolumn{2}{|c|}{ BO sürítmény } \\
\cline { 2 - 3 } & A & B \\
\hline frissen, nedvesen & 66300 & 69450 \\
\hline $\begin{array}{l}2 \text { hét tárolás után, } \\
\text { szárazon }\end{array}$ & 52230 & 67880 \\
\hline $\begin{array}{l}4 \\
\text { hét tárolás után, } \\
\text { szárazon }\end{array}$ & 42200 & 52840 \\
\hline
\end{tabular}

4. táblázat: Bogyós gyümölcsféleségeket tartalmazó súrítmény felhasználásával előállított mikrokapszulák antioxidáns kapacitása $(\mathrm{mg} / \mathrm{kg}$ AA) a tárolási kísérlet különböző fázisaiban
A bogyós gyümölcsök kivonatát és kereskedelmi forgalomban kapható gyümölcs súrítményt tartalmazó mikrokapszulák rövid távú tárolási vizsgálatainak tapasztalatai alapján úgy határoztunk, hogy a hosszabb távú eltartási vizsgálatokat a BO jelű bogyós gyümölcs súrítményt tartalmazó mikrokapszulákkal kezdjük meg.

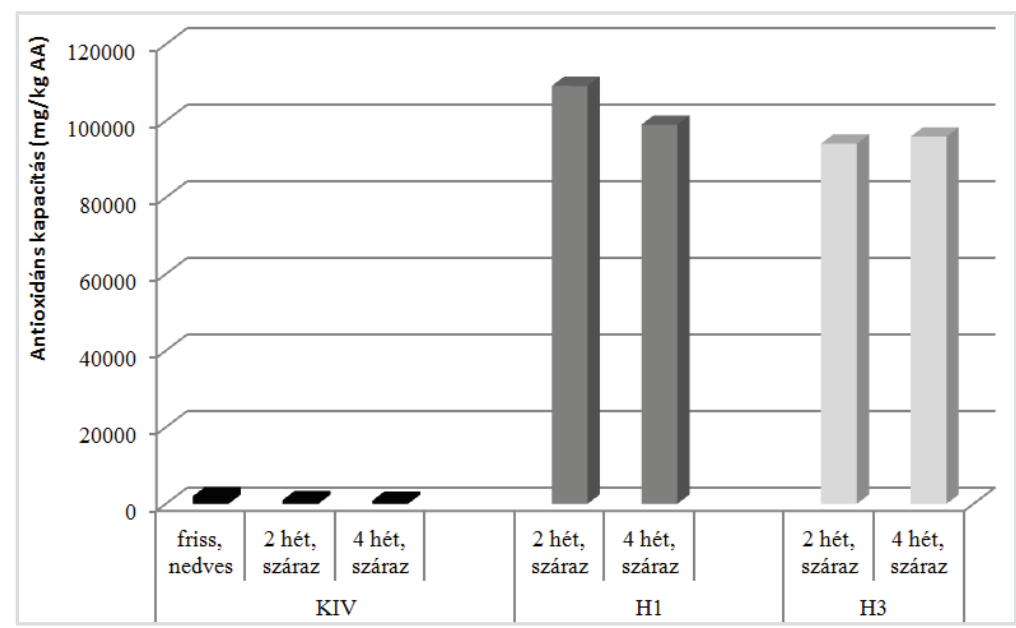

4. ábra: Homoktövis kivonatát (KIV), valamint homoktövis sürítményt (H1 és H3) tartalmazó mikrokapszulák antioxidáns kapacitásának (mg/kg AA) alakulása a rövid távú tárolási kísérletek során

Az 1. ábrán a saját készítésű homoktövis kivonat, valamint kétféle homoktövis súrítmény felhasználásával készült mikrokapszulák antioxidáns kapacitás értékeit hasonlítjuk össze. A diagramon ábrázolt eredmények bizonyítják, hogy a homoktövis súrítményeket tartalmazó kapszulák antoxidáns kapacitása akár két nagyságrenddel is meghaladhatja a vizes kivonatot tartalmazó kapszulákra mért értékeket, ezért a hosszabb távú eltartási kísérletekben már csak 
a homoktövis súrítményt tartalmazó mikrokapszulákat szerepeltetjük.

\section{ÖSSZEFOGLALÁS}

A gyógynövények és bogyós gyümölcsök mikrokapszulázására irányuló kísérleteink első eredményeit összegezve megállapíthatjuk, hogy a két gyógynövény esetében az „in situ gélesedés" módszerével elóállított mikrokapszulák alkalmasak a kivonatban megtalálható antioxidáns vegyületek környezeti hatásoktól való megóvására, ezeket a kapszulákat - módosított összetételben - érdemes hosszabb távú tárolási kísérleteknek alávetni. A fekete bodza, a szeder és a cseresznye esetében már a kapszulázáshoz felhasznált extraktum antioxidáns kapacitása is elmaradt a várakozásoktól és ezek az értékek tovább csökkentek a tárolás során. A bogyós gyümölcsök kivonatát tartalmazó súrítmény felhasználásával előállított mikrokapszulák azonban kedvező antioxidáns kapacitás értékeket mutattak a rövid távú tárolási kísérlet végén is, így a hosszabb távú vizsgálatainkat is ezekkel a kapszula-változatokkal fogjuk elvégezni. A homoktövist tartalmazó kapszulák esetében a kereskedelmi forgalomban kapható sürítmény felhasználásával előállított mikrokapszulák antioxidáns kapacitása kiemelkedő, ezért a hosszabb távú eltartási kísérletekben ezeket a kapszulákat fogjuk alkalmazni.

A kutatás a TÁMOP-4.2.4.A/2-11/1-2012-0001 azonosító számú Nemzeti Kiválóság Program Hazai hallgatói, illetve kutatói személyi támogatást biztosító rendszer kidolgozása és múködtetése konvergencia program címü kiemelt projekt keretében zajlott. A projekt az Európai Unió támogatásával, az Európai Szociális Alap társfinanszírozásával valósul meg. 